\title{
Research on Physical and Engineering Properties of Unstabilised Soil
}

\author{
Alina Elizabeth Suresh, P. D. Arumairaj, K. Sundarayamini
}

\begin{abstract}
Soil improvement techniques are inevitable due to the severe hazards caused by excessive settlement of foundation, debris flow, destructive landslides and the further softening by means of infiltration of prolonged rainfall. The environmentally sustainable technique that utilizes a biological process for biomineralization is Microbial Induced Calcite Precipitation (MICP). Biomineralization is the process in which living organisms produce minerals. There are different metabolic activities that lead to MICP such as ureolysis, denitrification, ammonification, photosynthesis, sulphate reduction and methane reduction. In this study, the photosynthetic soil-borne bacteria is used to enhance the soil stability. The photosynthetic bacteria is isolated from the soil, the characteristic growth is studied and the most efficient strain is selected to be injected back into the soil. The final properties of the soil are tested and are expected to increase its strength. The initial and final variations in the surface of the soil are studied using SEM analysis and EDAX.

Index Terms - Biomineralization, photosynthetic bacteria, soil improvement.
\end{abstract}

\section{INTRODUCTION}

Landslide hazard is one of the most significant hazards that affect different parts of India every year during the rainy season and annual recurrence. There is a variation in the degree of landslide incidences in various hill ranges. Increase in population and rapid urbanization has led to expansion of construction activities in hilly terrains and has catapulted frequency of landslides to dramatic proportions inrecent decades. The Nilgiris district in the Western Ghats of India has a long history of disastrous landslide events. In the recent times casualties and damage due to landslides have increased in the Nilgiri Hills. Generally October to December is the season for landslide in the Nilgiris. Most of these landslides are triggered by the heavy intense rainfall in the district. About 1150 small, medium and bigger size landslides were reported within five days from 10 to 15 November, 2009, and taken away about 80 human lives, also the vast damage reported on houses, roads and railway lines.

Revised Manuscript Received on April 12, 2019.

Alina Elizabeth Suresh,M.Tech Scholar, Environmental Engineering, Karunya Institute of Technology and Sciences. Coimbatore, Tamil Nadu, India.

Dr. P. D. Arumairaj, Professor \& Head, Department of Civil Engineering, Karunya Institute of Technology and Sciences.Coimbatore, Tamil Nadu, India.

K. Sundarayamini,Assisstant Professor, Department of Civil Engineering, Karunya Institute of Technology and Sciences.Coimbatore, Tamil Nadu, India.

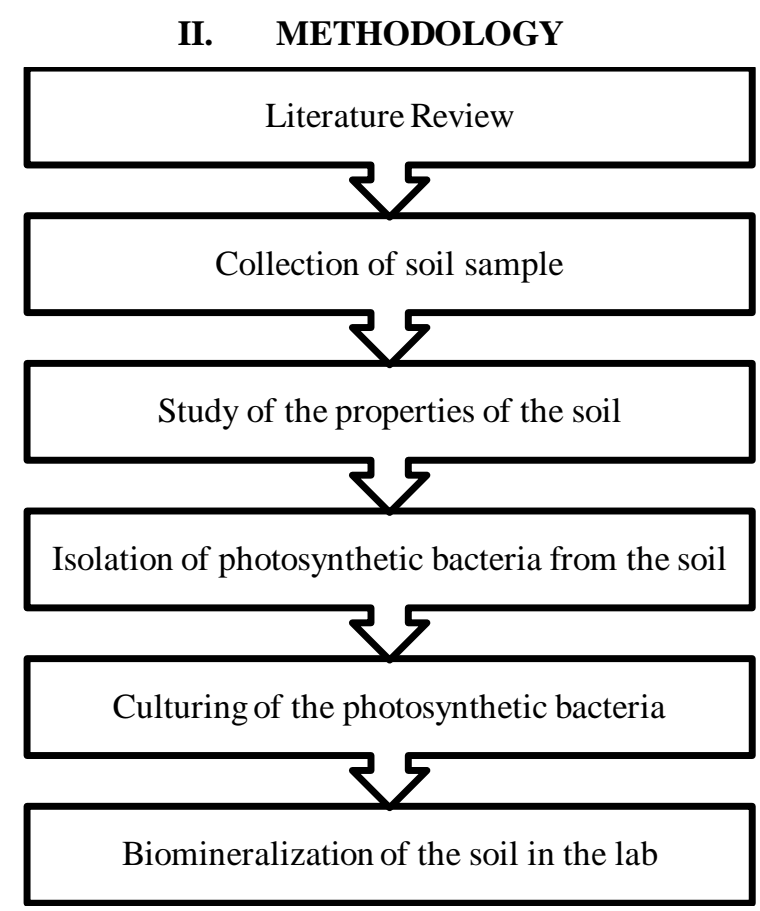

SOIL SAMPLE

The soils are lateritic in origin, derived from charnokites known as Nilgiri gneiss. Climatic conditions favour intense chemical weathering of minerals. The soil is yellowish brown or reddish brown. It is noted that the Nilgiri soils are non-erodable owing to their lateritic origin, low erosion rate and high percentage of water stable aggregates. Notwithstanding equitable rainfall distribution and nonerodability of soils, the erosion hazards are alarming due to poor agricultural practices and land uses. Land conversions for vegetable cultivation, cultivation on steep slopes, construction activity etc have caused landslides.

The soil sample to be stabilized is obtained near the Ooty Lake in the Nilgiris district of Ooty, Tamil Nadu.

\section{RESULTS AND DISCUSSION}

1. Moisture content

2. Specific gravity test

3. Sieve analysis test

4. Liquid limit test

5. Plastic limit test

6. Bulk density

7. $\mathrm{pH}$ test

8. Unconfined compression strength test

Published By:

Blue Eyes Intelligence Engineering 


\section{MOISTURE CONTENT RESULTS}

The moisture content of the soil is $35.71 \%$

\section{SPECIFIC GRAVITY RESULTS}

The specific gravity of the soil is 2.41

SIEVE ANALYSIS RESULTS

\begin{tabular}{|c|c|c|c|c|}
\hline Sieve & $\begin{array}{c}\text { Retained } \\
\text { wt }\end{array}$ & $\begin{array}{c}\text { Retained } \\
\text { \% }\end{array}$ & $\begin{array}{c}\text { Cumulative } \\
\text { \% }\end{array}$ & Pass \% \\
\hline 4.75 & 0 & 0 & 0 & 100 \\
\hline 3.35 & 5 & 1 & 1 & 99 \\
\hline 2.36 & 5 & 1 & 2 & 98 \\
\hline 1.18 & 25 & 5 & 7 & 93 \\
\hline 0.6 & 25 & 5 & 12 & 88 \\
\hline 0.425 & 20 & 4 & 16 & 84 \\
\hline 0.3 & 30 & 6 & 22 & 78 \\
\hline 0.15 & 40 & 8 & 30 & 70 \\
\hline 0.075 & 30 & 6 & 36 & 64 \\
\hline Pan & 315 & 64 & 100 & 0 \\
\hline
\end{tabular}

Coarse Sand $=2 \%$

$>$ Medium Sand $=10 \%$

$>$ Fine Sand $=18 \%$

$>$ Silt \& Clay $=64 \%$

\section{LIQUID LIMIT RESULTS}

\begin{tabular}{|c|c|c|c|c|}
\hline $\begin{array}{c}\text { Number } \\
\text { of blows }\end{array}$ & 35 & 28 & 18 & 12 \\
\hline $\begin{array}{c}\text { Moisture } \\
\text { content }\end{array}$ & 40 & 50 & 66.67 & 80 \\
\hline
\end{tabular}

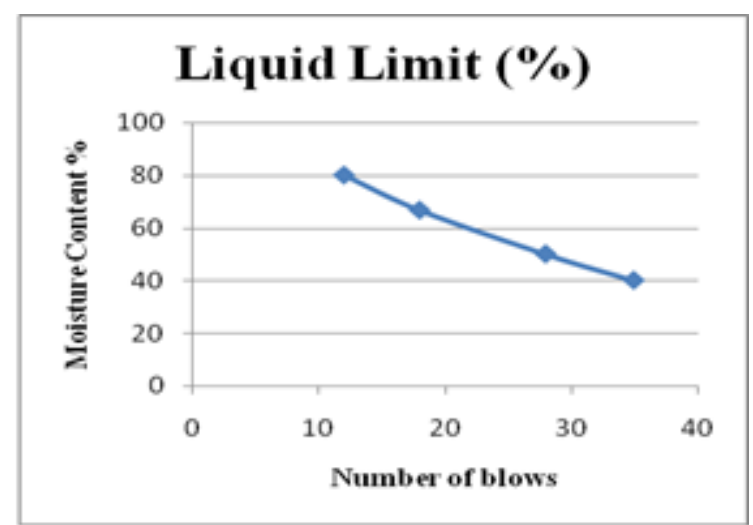

The liquid limit of the soil is $\mathbf{5 4 \%}$

\section{PLASTIC LIMIT RESULTS}

\begin{tabular}{|c|c|c|c|}
\hline $\begin{array}{c}\text { Empty wt } \\
\text { of } \\
\text { container } \\
\text { (g) }\end{array}$ & $\begin{array}{c}\text { Wt of } \\
\text { container } \\
\text { + wet soil } \\
\text { (g) }\end{array}$ & $\begin{array}{c}\text { Wt of } \\
\text { container } \\
\text { + dry soil } \\
(\mathbf{g})\end{array}$ & $\begin{array}{c}\text { Plastic } \\
\text { limit }(\boldsymbol{\%})\end{array}$ \\
\hline 11 & 16 & 12 & 33.33 \\
\hline 13 & 17 & 12 & 41.8 \\
\hline 11 & 17 & 13 & 30.8 \\
\hline
\end{tabular}

$>$ The plastic limit of the soil $\left(\mathrm{W}_{\mathrm{P}}\right)$ is $35.24 \%$.

$>$ The plasticity index $\left(\mathrm{I}_{\mathrm{P}}\right)=\mathrm{W}_{\mathrm{L}}-\mathrm{W}_{\mathrm{P}}=18.75$

According to the code book IS 1948 - 1970, since the soil contains silt and clay with high compressibility and liquid limit greater than 50 , i.e. $54 \%$, the soil comes under the category of $\mathrm{OH}$, organic clays of medium to high plasticity.

\section{BULK DENSITY TEST RESULTS}

$>$ The bulk density of the soil is $1 \mathrm{~g} / \mathrm{cc}$.

$>$ The particle density of the soil is $2.22 \mathrm{~g} / \mathrm{cc}$.

$>$ The pore space volume is $11 \mathrm{ml}$.

$>$ The pore space percent is $55 \%$.

The pore space in the soil sample is very high that is greater than 50. Hence, the soil is very weak in condition.

\section{UNCONFINED COMPRESSION STRENGTH TEST} RESULTS

\begin{tabular}{|c|c|c|c|c|c|}
\hline $\begin{array}{c}\text { Dial } \\
\text { value } \\
(\mathbf{m m})\end{array}$ & $\begin{array}{c}\text { Proving } \\
\text { Ring }\end{array}$ & Load (P) & $\begin{array}{c}\text { Axial } \\
\text { strain }\end{array}$ & Area & $\begin{array}{c}\text { Stress } \\
(\mathbf{P} / \mathbf{A})\end{array}$ \\
\hline 0.5 & 4.8 & 5.92 & 0.007 & 110.73 & 0.053 \\
\hline 1 & 7.8 & 9.63 & 0.014 & 112.3417 & 0.0856 \\
\hline 1.5 & 12 & 14.8 & 0.021 & 114.8 & 0.128 \\
\hline 2 & 14 & 17.2 & 0.029 & 118.12 & 0.1461 \\
\hline 2.5 & 16.2 & 19.9 & 0.035 & 122.54 & 0.1631 \\
\hline 3 & 18.2 & 22.5 & 0.043 & 128.02 & 0.1754 \\
\hline 3.5 & 20 & 24.6 & 0.05 & 134.76 & 0.1831 \\
\hline 4 & 23.6 & 29.1 & 0.057 & 142.921 & 0.2037 \\
\hline 4.5 & 26.4 & 32.5 & 0.064 & 152.726 & 0.2133 \\
\hline 5 & 28 & 34.5 & 0.071 & 164.46 & 0.21 \\
\hline 5.5 & 31.8 & 39.2 & 0.078 & 178.48 & 0.2198 \\
\hline 6 & 35.2 & 43.4 & 0.085 & 195.21 & 0.2225 \\
\hline 6.5 & 43.2 & 53.3 & 0.092 & 215.19 & 0.2477 \\
\hline 7 & 47.8 & 58.9 & 0.1 & 239.1 & 0.257 \\
\hline 7.5 & 14.2 & 17.5 & 0.101 & 267.77 & 0.0654 \\
\hline 8 & 6.4 & 7.89 & 0.114 & 302.336 & 0.0261 \\
\hline
\end{tabular}

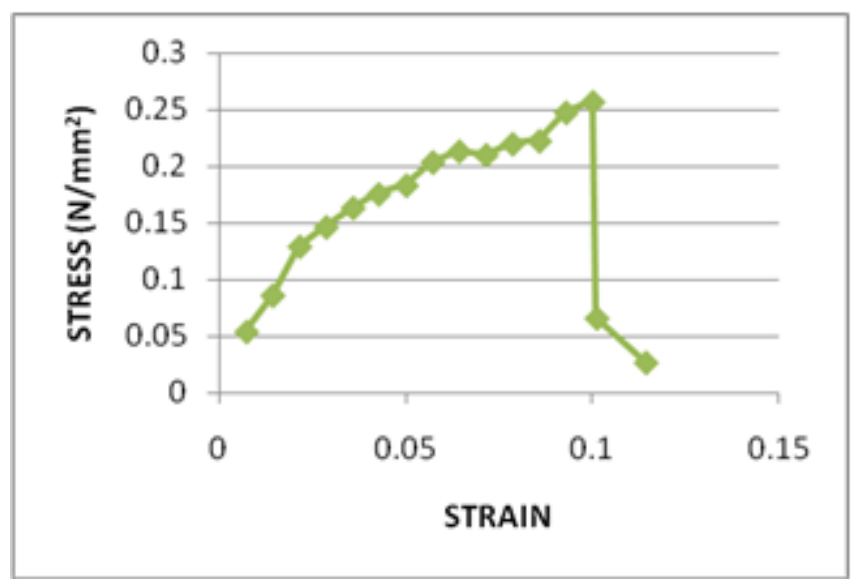

According to the graph plotted for stress against axial strain, the soil sample has shown $25 \mathrm{kPa}$ of strength in the unconfined compression strength test at $15 \%$ moisture content.

\section{pH TEST RESULTS}

The $\mathrm{pH}$ of the soil is determined to be 5.16 . The $\mathrm{pH}$ soil sample is in the optimal range.

\section{SEM ANALYSIS OF SOIL SAMPLE}

Published By: 


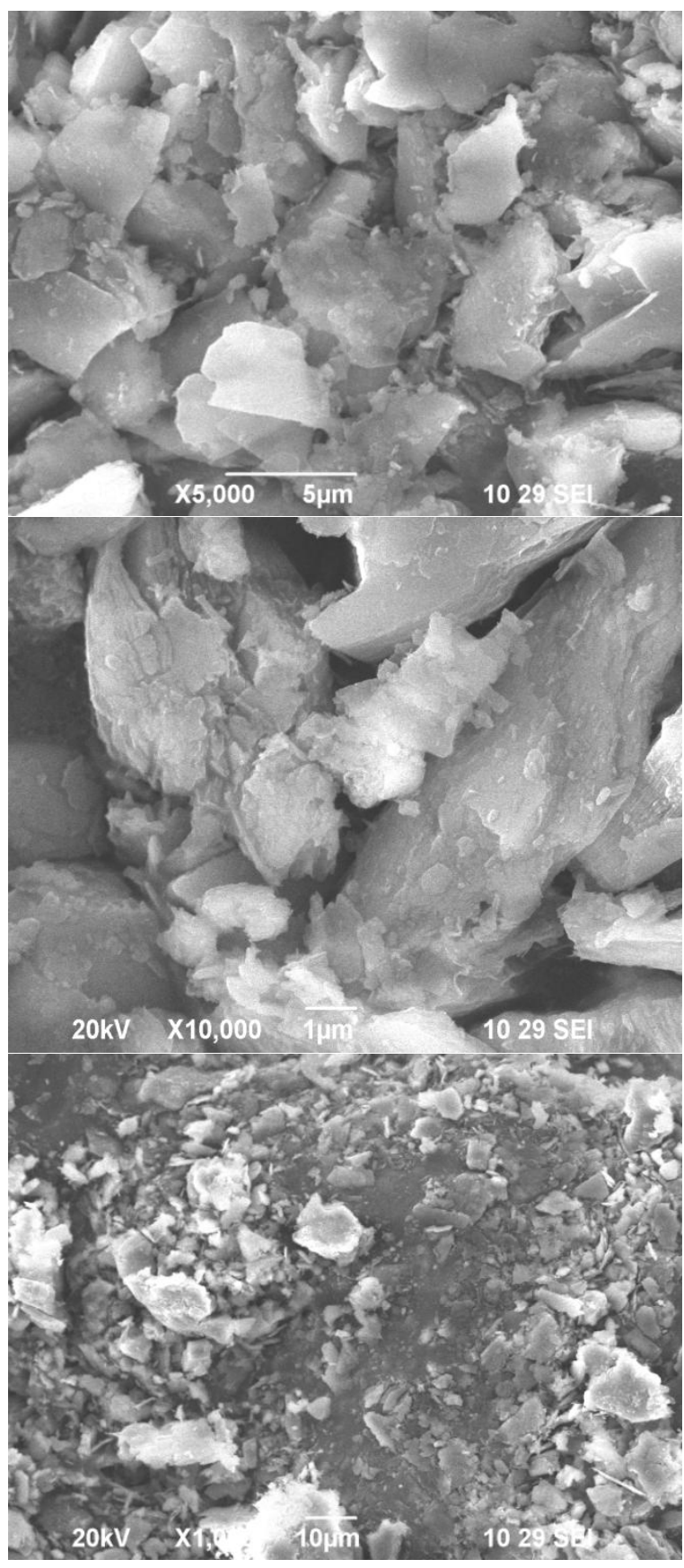

EDAX ELEMENTAL ANALYSIS OF SOIL SAMPLE

\begin{tabular}{|c|c|c|c|c|c|}
\hline Element & $\begin{array}{c}\text { App } \\
\text { Conc. }\end{array}$ & $\begin{array}{c}\text { Intensity } \\
\text { Corrn. }\end{array}$ & $\begin{array}{c}\text { Weight } \\
\text { \% }\end{array}$ & $\begin{array}{c}\text { Weight } \\
\text { \% Sigma }\end{array}$ & $\begin{array}{c}\text { Atomic } \\
\%\end{array}$ \\
\hline $\mathrm{O} \mathrm{K}$ & 54.24 & 1.1228 & 54.75 & 0.51 & 69.75 \\
\hline $\mathrm{Al} \mathrm{K}$ & 12.00 & 0.8336 & 16.30 & 0.29 & 12.31 \\
\hline $\mathrm{Si} \mathrm{K}$ & 13.02 & 0.7441 & 19.80 & 0.33 & 14.37 \\
\hline $\mathrm{K} \mathrm{K}$ & 1.26 & 0.9908 & 1.44 & 0.12 & 0.75 \\
\hline Fe K & 5.67 & 0.8326 & 7.71 & 0.30 & 2.81 \\
\hline Total & \multicolumn{5}{|c|}{$\mathbf{1 0 0}$}
\end{tabular}
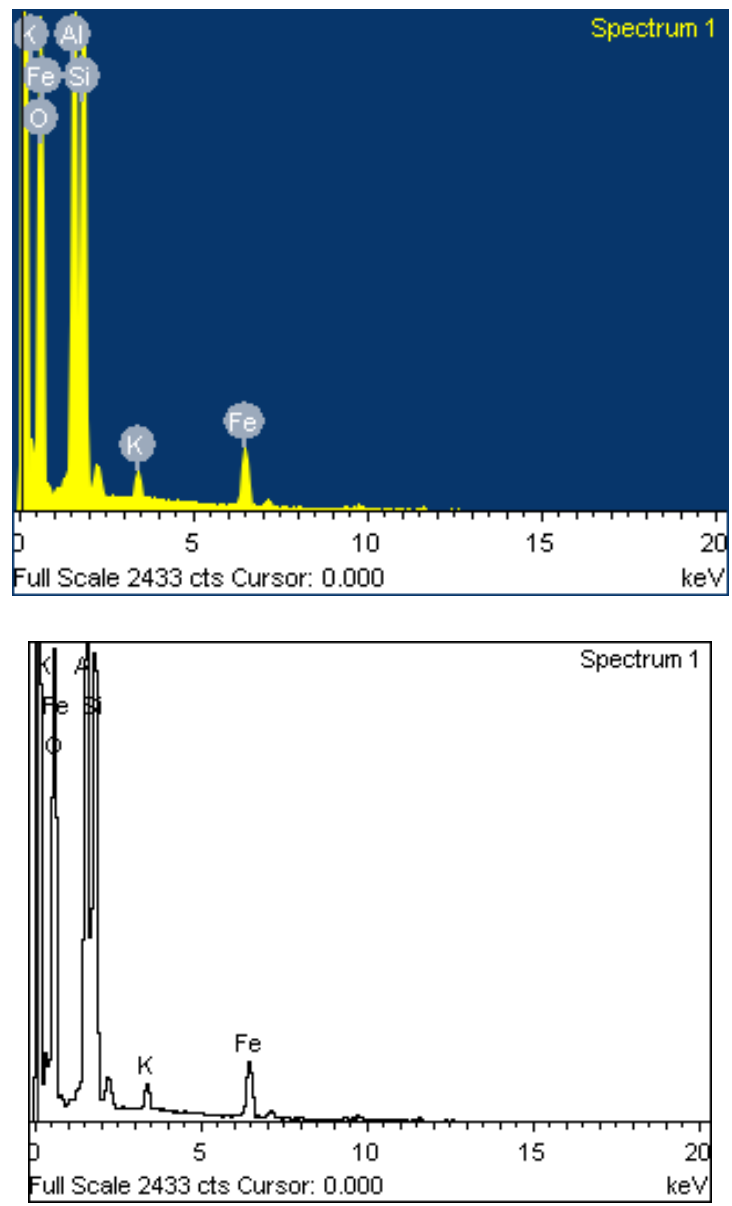

\section{CONCLUSION}

The soil sample was collected and its properties were studied through the physical soil tests such as moisture content, specific gravity, liquid limit, plastic limit, bulk density, and particle density, pore space volume and pore space percent. The $\mathrm{pH}$ of the soil was also determined. The surface morphology of the soil was examined with the help of Scanning Electron Microscope (SEM) and the elemental analysis of the soil was determined using the Energy Dispersive X-Ray Analysis (EDAX). Based on the results it is concluded that there is further scope for the stabilization of the soil.

\section{REFERENCE}

1. Mugnai, G., Rossi, F., Martin Noah Linus Felde, V., Colesie, C., Büdel, B., Peth, S., Kaplan, A. and De Philippis, R. (2018). "The potential of the cyanobacteriumLeptolyngbyaohadii as inoculum for stabilizing bare sandy substrates". Soil Biology and Biochemistry, 127, pp.318-328.

2. Rippka, R., 1988. [1] Isolation and purification of cyanobacteria. In Methods in enzymology (Vol. 167, pp. 3-27). Academic Press.

3. Rossi, F., Li, H., Liu, Y. and De Philippis, R. (2017). Cyanobacterial inoculation (cyanobacterisation): Perspectives for the development of a standardized multifunctional technology for soil fertilization and desertification reversal. Earth-Science Reviews, 171, pp.28-43.

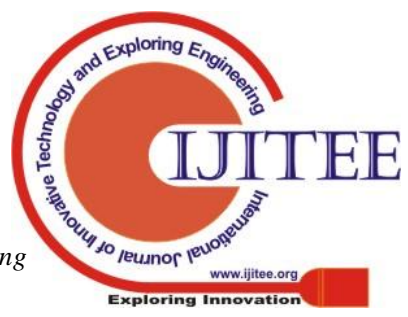


4. DeJong, J., Mortensen, B., Martinez, B. and Nelson, D. (2010). Bio-mediated soil improvement. Ecological Engineering, 36(2), pp.197-210.

5. Soon, N., Lee, L., Khun, T. and Ling, H. (2013). Improvements in engineering properties of soils through microbial-induced calcite precipitation. KSCE Journal of Civil Engineering, 17(4), pp.718-728.

6. Whiffin, V., van Paassen, L. and Harkes, M. (2007). Microbial Carbonate Precipitation as a Soil Improvement Technique. Geomicrobiology Journal, 24(5), pp.417-423.

7. Umar, M., Kassim, K. and Ping Chiet, K. (2016). Biological process of soil improvement in civil engineering: A review. Journal of Rock Mechanics and Geotechnical Engineering, 8(5), pp.767-774.

8. Van Paassen, L., Daza, C., Staal, M., Sorokin, D., van der Zon, W. and van Loosdrecht, M. (2010). Potential soil reinforcement by biological denitrification. Ecological Engineering, 36(2), pp.168-175.

9. Moravej, S., Habibagahi, G., Nikooee, E. and Niazi, A. (2018). Stabilization of dispersive soils by means of biological calcite precipitation. Geoderma, 315, pp.130-137.

10. Mortensen, B., Haber, M., DeJong, J., Caslake, L. and Nelson, D. (2011). Effects of environmental factors on microbial induced calcium carbonate precipitation. Journal of Applied Microbiology, 111(2), pp.338-349. 